\begin{tabular}{l} 
JOURNAL OF EMPOWERMENT \\
VOL. 2, No. 1, Juni 2021, h. 101-110 \\
ISSN 2580-0620 (Print) \\
ISSN 2597-9809 (Online) \\
Available Online at https://jurnal.unsur.ac.id/index.php/JE \\
\hline \hline
\end{tabular}

\title{
PELATIHAN GOOGLE DOCS UNTUK MENINGKATKAN KOLABORASI PENYUSUNAN RPP PADA SD 20 PALMERAH JAKARTA BARAT
}

\section{GOOGLE DOCS TRAINING TO IMPROVE COLLABORATION FOR RPP DEVELOPMENT AT SD 20 PALMERAH JAKARTA BARAT}

\author{
Dewi Anjani ${ }^{1}$, Desi Novianti ${ }^{2}$, \& Ali Sadikin Wear ${ }^{3}$ \\ Universitas Indraprasta PGRI \\ dewiunindra@gmail.com \\ 2Universitas Indraprasta PGRI \\ diosenore@gmail.com \\ 3Universitas Indraprasta PGRI \\ alisadikinwear@gmail.com
}

Masuk : 23 Februari $2021 \quad$ Penerimaan : 05 Mei 2021

Publikasi : 01 Juni 2021

\begin{abstract}
ABSTRAK
Pelaksanaan pembelajaran di kelas memerlukan persiapan yang matang, seperti merancang kegiatan yang akan dilakukan guru dan siswa dalam proses pembelajaran. Rencana Pelaksanaan Pembelajaran (RPP) bertujuan memudahkan pencapaian tujuan pembelajaran.Sedangkan penyusunan dokumen RPP harus berkolaborasi antara 2-3 orang guru. Dalam kondisi pandemi ini pembuatan RPP sangat sulit karena media yang digunakan membuat RPP adalah media online. Seorang guru mengirimkan pekerjaannya ke guru atau karyawan lain untuk ditambahkan atau diedit. Guru lainnya kemudian akan melakukan hal yang sama; proses ini menyebabkan satu dokumen memiliki banyak nama file dan konten yang berbeda.Salah satu solusi dari permasalahan tersebut adalah malaksankan kegiatan pengabdian kepada masyarakat yang mengenalkan dan memberikan Pelatihan Aplikasi Kolaborasi Kerja Dalam Rangka Penyusunan Dokumen Perencanaan Pembelajaran di SD 20 Pal Merah Jakarta Barat.Harapan dari pelaksanaan kegiatan ini adalah pembelajaran dokumen dapat terlaksana tepat waktu dan memudahkan guru dan karyawan dalam membuat RPP dalam mengerjakan dokumen.
\end{abstract}

Kata Kunci : Aplikasi Kolaborasi; Google Docs; Perencanaan Studi

\begin{abstract}
Lesson Plan aims to make it easier to achieve learning objectives. Meanwhile, the preparation of RPP documents must collaborate between 2-3 teachers or employees. In this pandemic condition, makinglesson Plan is very difficult because the media used to make Lesson Plan is online media. A teacher will send his work to other teachers or employees to add or edit. The other teachers will then do the same; this process causes one document to have many different file names and contents. One solution to this problem is to hold community service activities that introduce and provide Work Collaboration Application Training in the Context of Preparing Learning Planning Documents at SD 20 Pal Merah. The hope of implementing this activity is that document learning can be carried out on time and make it easier for teachers and employees to create lesson plans in working on document.
\end{abstract}

Keywords : Collaboration Application; Google Docs; Study Planning 


\section{A. PENDAHULUAN}

Berdasarkan Permendikbud No. 15 tahun 2018 tentang pemenuhan beban kerja guru, kepala sekolah dan pengawas sekolah, dan Permendikbud No. 22 tentang Standar Proses Pendidikan Dasar dan Menengah, bahwasanya seorang guru harus mempersiapkan perencanaan dalam mengajar. (Kauffman, 1972)menjelaskan perencanaan adalah suatu proyeksi tentang apa yang diperlukan dalam rangka mencapai tujuan absah dan bernilai yang di dalamnya mencakup elemen-elemen:

1. Mengidentifikasi dan mendokumentasikan kebutuhan;

2. Menentukan kebutuhan-kebutuhan yang perlu diprioritaskan;

3. Spesifikasi rinci hasil yang dicapai dari tiap kebutuhan yang diprioritaskan;

4. Identifikasi persyaratan untuk mencapai tiap-tiap pilihan;

5. Skuensi hasil yang diperlukan untuk memenuhi kebutuhan yang dirasakan, dan

6. Identifikasi strategi alternatif yang mungkin dan alat atau toolsuntuk melengkapi tiap persyaratan dalam mencapai tiap kebutuhan, termasuk di dalamnya merinci keuntungan dan kerugian tiap strategi dan alat yang dipakai.

Menurut Sanjaya (2017) perencanaan dimulai dari penetapan tujuan yang akan dicapai melalui analisis kebutuhan serta dokumen yang lengkap, kemudian menetapkan langkah-langkah yang harus dilakukan untuk mencapai tujuan tersebut. Ketika merencanakan maka pola pikir diarahkan bagaimana agar tujuan itu dapat dicapai secara efektif dan efisien (Marlina, 2017).

Berdasarkan Ananda (2019) bahwa perencanaan memiliki empat unsur yang melingkupinya. Keempat unsur tersebut yaitu:

1. Adanya tujuan yang harus dicapai;

2. Adanya strategi untuk mencapai tujuan;

3. Sumber daya yang dapat mendukung; dan

4. Implementasi setiap keputusan.

Perencanaan dalam konteks pembelajaran sebagai proses penyusunan materi pelajaran, penggunaan media pembelajaran, penggunaan pendekatan dan metode pembelajaran, dan penilaian dalam suatu alokasi waktu yang akan dilaksanakan pada masa tertentu untuk mencapai tujuan yang telah ditentukan (Dolong, 2016; Khumyati, 2017).

Perencanaan pembelajaran dibuat oleh guru dan karyawan yang nantinya akan di kelompokkan kedalam kelompok kecil sesuai dengan bidang masing-masing. Seperti bidang kurikulum, kesiswaan, sarana dan prasarana, pengembangan diri dan humas serta bidang penyusunan silabus dan rencana pembelajaran semester (RPS) (Lismina, 2017; Majid, 2011 ).

Sekolah Dasar (SD) 20 Palmerah, Jakarta Barat merupakan tempat pendidikan anak yang berusia antara 7 sampai dengan 13 tahun sebagai pendidikan di tingkat dasar yang dikembangkan sesuai dengan satuan pendidikan, potensi daerah/karakteristik daerah, sosial budaya masyarakat setempat bagi siswa.

Perencanaan pembelajaran pada SD 20 Pal Merah, biasanya disusun oleh guru dan karyawan yang dilaksanakan pada akhir semester. Kegiatan ini biasanya disebut dengan rapat keria (Raker) dimana guru dan karyawan akan dijadwalkan dan dikumpulkan pada suatu tempat dalam 2-3 hari. Dalam pembuatan perencanaan pembelajaran, guru dan karywanan harus mengumpulkan dokumen-dokumen yang lalu dan menganalisis dokumen tersebut apakah sudah sesuai dengan kebutuhan untuk tahun ajaran berikutnya. Penyusunan RPP selalu dilakukan secara berkolabiorasi.

Berdasarkan Kamus besar bahasa Indonesia Kolaborasi adalah kerja sama (KBBI, 2021), sementara itu Menurut Thomson \& Perry (2006), kolaborasi adalah proses di mana para pemangku kepentingan berinteraksi dan bernegosiasi, bersama, dan 
berhubungan satu sama lain berdasarkan aturan yang disepakati bersama. Kolaborasi dapat mengurangi konflik, meminimalkan kegagalan perencanaan pengembangan, membuat strategi yang memenuhi kebutuhan semua pihak yang terlibat dan menghasilkan solusi jangka panjang. Prinsip utama kolaborasi adalah transparansi proses, keragaman, dan keterwakilan kepentingan pemangku kepentingan, serta keterlibatan semua pemangku kepentingan dalam pengambilan satu keputusan. Aspek kolaborasi adalah dialog, membangun komitmen, tujuan, dan kesepakatan bersama (Batara, Syafar, Palutturi, \& Stang, 2018).

Permasalahannya saat ini adalah kegiatan penyusunan RPP tidak dapat lagi dilaksanakan pada satu tempat, ini dikarena situsai covid-19. Hal ini mengakibatkan adanya pembatasan dalam berkumpul(Sudjatmiko \& Kusrini, 2011), sementara pekerjaan pembuatan dokumen pembelajaran harus berkolabirasi antara 2-3 guru atau karywaan, hal ini sangat menyulitkan (Kemdikbud, 2020; Oviana, 2013; Sukardjo, Khasanah, Solehatin, \& Sudrajat, 2020). Implementasi kolaborasi dalam pembuatan RPP pada saat ini adalah seorang guru akan mengirim hasil kerjanya kepada guru atau karyawan yang lain dalam kelompok untuk dilakukan penambahan, atau pengeditan dokumen tersebut(Mawardi, 2019; Yatmini, 2017).

Sementara itu berdasarkan penelitian pendahuluan dengan menyebarkan kuisioner kepada guru SD 20, yang dilaksanakan pada bulan september 2020. Dimana pertanyaan berdasarkan indikator cara pengerjaan RPP pada saat pandemi, alat bantu dalam mengerjakan RPP, dan optimasi waktu dalam membuat RPP. Hasil penelitian tersebut adalah $43 \%$ guru memberikan satu dari 3 guru yang diberikan wewenang untuk membuat RPP atau hanya satu guru yang membuat RPP walaupun tugas ini adalah tugas kolaborasi. Kemudian $45 \%$ guru menggunakan alat bantu WA group dan email untuk melakukan kolaborasi dalam bekerja dan $85 \%$ guru merasa pembuatan RPP dengan pada saat pandemi secara online tidak optimal karena susahnya bekeria secara bersama-sama meski melalui WA group dan Email(Siswanto, 2020).

Pada saat ini, dari hasil penelitan awal permasalahn tersebut dapat diatasi dengan menggunakan whatsapp group dan email, dimana dokumen yang dikerjakan satu guru akan di kirim ke yang lain melalui whatsapp atau email, kemudian dokumen yang telah di perbaiki dikirm Kembali dengan cara yang sama. Hal ini menimbulkan beberapa perrmasalahan seperti terlalu banyaknya dokumen dengan nama yang sama sehingga terkadang salah mengedit dokumen. Terlalu banyak waktu tunggu, hingga dokumen yang dikerjakan menjadi lama dalam pengerjaannya.

Untuk memecahkan masalah tersebut, maka diadakan sebuah kegiatan pengabdian kepada masyarakat yang memperkenalkan dan pemberian Pelatihan Aplikasi Kolaborasi Pekerjaan Dalam Rangka Penyusunan Dokumen Perencanaan Belajar Pada Sekolah Dasar 20 Pal Merah, Jakarta Barat, sehingga dokumen pembelajaran dapat tepat waktu dikerjakan, dan memudahkan guru dan karyawan dalam mengerjakan dokumen.

Pelatihan ini menggunakan aplikasi open source yaitu google docs, yang dapat memberikan akses secara penuh pada saat melaksanaan pengabdian ini. Sehingga tidak ada kendalam dalam mengakses aplikasi.Target dalam kegiatan pengabdian pada masyarakat ini adalah pelatihan dimana mempraktikkan penggunaan aplikasi google docs dalam rangkakolabirasi pembuatan dokumen.

\section{B. METODE}

Pelaksanaannya secara daring, kegiatan dilaksanakan selama 4 kali pertemuan dengan masing-masing pertemuan selama $2 \frac{1}{2}$ (dua setengah jam) yang diperuntukan bagi para Guru Sekolah Dasar 20 Pal Merah, Jakarta Barat. Metode penelitian PKM 
ini, dilakukan dalam 3 tahap yaitu tahap Pra kegiatan, tahap pelaksanaan, dan tahap evaluasi.

Tahap pertama, Pra kegiatan dimana tahap ini tim melakukan survei awal untuk mengetahui kondisi peserta yang akan diberikan pelatihan (terutama guru dan karyawan yang berhubungan langsung dengan pembuatan RPP). Kemudian masuk ke tahap persiapan yaitu menyusun rancangan kegiatan yang akan dilakukan.

Tahap pelaksanaan yaitu melakukan pelatihan penggunaan google docs sebagai media pembuatan dokumen bersama, dimana pada tahap ini akan dilakukan penilaian awal dan akhir tentang pengenalan dan pemahan materi, pemberian materi dari tim PKM dan demontrasi oleh peserta secara kelompok untuk membuktikan bahwa peserta telah memahami materi yang telah didapat. Dimana daftar kegiatan PKMdapat dilihat pada tabel 1.

Table 1 Kegiatan PKM

\begin{tabular}{|c|c|c|c|}
\hline Waktu & $\begin{array}{c}\text { Pemateri/ } \\
\text { koordinator }\end{array}$ & $\begin{array}{l}\text { Jenis IPTEK yang akan } \\
\text { ditransfer kepada Mitra }\end{array}$ & Deskripsi Iptek \\
\hline $\begin{array}{c}9 \\
\text { november } \\
2020\end{array}$ & lbu Dewi & $\begin{array}{ll}\text { Pengenalan } & \text { beberapa } \\
\text { aplikasi } & \text { kolaborasi } \\
\text { pekerjaan } & \end{array}$ & $\begin{array}{l}\text { Memberikan penjelasan } \\
\text { beberapa aplikasi kolaborasi } \\
\text { pekerjaan, mendemontrasikan } \\
\text { menggunakan media meeting } \\
\text { daring seperti Gmeet }\end{array}$ \\
\hline $\begin{array}{c}16 \\
\text { november } \\
2020\end{array}$ & $\begin{array}{l}\text { Bapak Ali } \\
\text { Bu Desi }\end{array}$ & $\begin{array}{l}\text { Pelatihan menyiapkan } \\
\text { aplikasi, akun dan } \\
\text { kebuthan lainya, yang } \\
\text { berhubungan dengan } \\
\text { google dokumen }\end{array}$ & $\begin{array}{l}\text { Mendemontrasikan dan } \\
\text { langsung mempraktikan } \\
\text { aplikasi, akun dan kebutuhan } \\
\text { lainya, yang berhubungan } \\
\text { dengan google dokumen } \\
\text { secara daring }\end{array}$ \\
\hline $\begin{array}{c}23 \\
\text { november }\end{array}$ & $\begin{array}{l}\text { Peserta } \\
\text { Bu Dewi }\end{array}$ & $\begin{array}{l}\text { Peserta } \\
\text { mendemontrasikan }\end{array}$ & $\begin{array}{l}\text { Peserta mendemontrasikan dan } \\
\text { langsung mempraktikan }\end{array}$ \\
\hline ח202 & Bu Desi & $\begin{array}{lr}\text { secara } & \text { langsung } \\
\text { pembuatan } & \text { sebuah } \\
\text { dokumen } & \text { dan } \\
\text { mengerjakan } & \text { secara } \\
\text { kolaborasi } & \end{array}$ & $\begin{array}{l}\text { pembuatan satu dokumen pada } \\
\text { google dokumen secara } \\
\text { bersama-sama melalui daring }\end{array}$ \\
\hline $\begin{array}{c}30 \\
\text { november } \\
2020\end{array}$ & $\begin{array}{l}\text { Peserta } \\
\text { Bapak Ali } \\
\text { Bu Desi }\end{array}$ & $\begin{array}{l}\text { Peserta } \\
\text { mendemontrasikan } \\
\text { secara langsung } \\
\text { pembuatan sebuah } \\
\text { dokumen dan } \\
\text { mengerjakan secara } \\
\text { kolaborasi (lanjutan) }\end{array}$ & $\begin{array}{l}\text { Peserta mendemontrasikan dan } \\
\text { langsung mempraktikan dan } \\
\text { latihan dalam pembuatan satu } \\
\text { dokumen pada google } \\
\text { dokumen secara bersama-sama } \\
\text { melalui daring }\end{array}$ \\
\hline
\end{tabular}

Tahap terakhir adalah evaluasi, dimana tim melakukan evaluasi kegiatan pada tahap pelaksanaan. Evaluasi diambil dari pemberian kuisioner dan hasil observasi pada saat peserta demontrasi hasil pelatihan

\section{HASIL ATAU PEMBAHASAN}

Program pengolah kata adalah aplikasi yang digunakan untuk membuat teks, tulisan atau suatu dokumen. Pada mulanya, program pengolah kata yang ada hanya sebatas Word Star (WS), Chi Writer (CW) dan Word Perfect (WP). Program ini terus berkembang hingga saat ini yang paling populer salah satunya adalah Microsoft Word (Kuswayanto, 2006). 
Dimana keuntungan menggunakan program pengolah kata ini adalah (Kuswayanto, 2006):

1. Naskah yang ditulis tersusun rapi

2. Mudah mengoreksi ketika terjadi kesalahan

3. Dapat menggunakan berbagai jenis huruf

4. Data yang disimpan dalam komputer dapat dibuka kembali jika ada perbaikan

5. Dapat dicetak di atas kertas dengan tinta hitam atau warna

Program pengolah kata, pada awalnya masih bersifat offline dimana aplikasi ini hanya dapat digunakan perorangan. Hingga pada tahun 2006 perusahann google merilis produk baru yaitu google doc yangmerupakan pengolah kata yang dapat di akses dimana saja (online).

Google doc merupakan suatu layanan pengolah kata daaring yang diberikan kepada pengguna Google secara gratis (Baker, 2018). Google Docs adalah versi lain yang memungkinkan pengguna aplikasi pengolah kata untuk membuat, mengedit, dan membagikan dokumen tertulis secara online. Kelebihan dari google doc daring adalah fasilitas yang memungkinkan peserta untuk saling berkolaborasi dalam bekerja untuk saru dokumen.

Dalam pembuatan RPP biasanya menggunakan aplikasi pengolah kata, dimana jenis aplikasi yang digunakan masih bersifat offline. Sementara dengan kondisi pandemi pada saat ini, dimana setiap pekerjaan diharapkan bisa bersifat online dan juga dapat memudahkan pekerjaan yang dapat dikerjakan bersama-sama maka dibutuhkan sebuah program aplikasi online dan juga dapat berkolaborasi seperti Google doc.

Pengabdian kepada masyarakat ini dilaksanakan pada tanggal 9-23 november 2020 di SDN 20 Pal Merah, Jakarta Barat. Kegiatan ini bertujuan memberikan pelatihan kepada Guru dan karyawan dalam menggunakan fasilitas program pengolah kata secara daring. Dengan diadakanya PKM ini diharapkan peserta dapat saling berkerjasama dalam mengerjakan penyusunan rencana belajar. Diharapkan dengan kegiatan ini guru dan karyawan dapat lebih efisiensi dalam ruang dan waktu pada saat mengerjakan dokumen pembelajaran, sehingga dokumen dapat dikumpulkan tepat waktu. Langkah-langkah kegiatan, yaitu :

1. Pra Kegiatan

Pra Kegiatan, pada tahap ini hasil dari survei yang diadakan awal bulan oktober 2020 adalah kondisi yang tidak memungkinkan untuk melaksanakan kegiatan secara tatap muka karena masih dalam kondisi pandemic covid, sehingga kegiatan akan dilaksanakan secara online dengan menggunakan media GMeet.

Setalah menetapkan pelaksanaan kegiatan kemudian melaksanakan tahapan persiapan, merupakan tahapan untuk menyiapkan bahan seperti slide presentasi, modul, link Gmeet, dan penilaian awal dan akhir. Slide presntasi, modul dan link Gmeet diberikan sehari sebelum pelaksanaan kegiatan yang diberikan melalui WA group, hal ini akan memudahkan peserta untuk mengakses kegiatan nanti.

Sementara penilaian awal dan akhir, masing -masing diberikan pada saat sebelum pemateri memberikan materi dan pada saat kegiatan akan berakhir. Penilaian ini disusun dengan indikator tentang pengetahuan dasar peserta terhadap program pengolahan daring terutama google doc, dan fungsi kolabrasi. Pertanyaan pertanyaan tersebut dibuat dengan google form dan disebarkan pada menu chat di Gmeeet dan WA Group.

Kemudian persiapan waktu pelaksanaan yang dikoordinasi wakil tim dengan perwakilan sekolah. Dari kegiatan ini dijadwalkan kegiatan akan dilaksanakan pada tanggal 9-30 november 2020, yang dilaksanakan setiap hari senin pukul 13.00-15.30 WIB. 


\section{Tahapan Pelaksanaan}

Tahapan pelaksanaan yaitu melakukan pelatihan penggunaan google docs sebagai media pembuatan dokumen bersama. Dimana peserta pelatihan adalah guru dan karywan, yang semua berjumlah 30 orang. Pelaksanaan ini dilaksanakan 4 hari yaitu pada bulan November setiap hari senin.

a. Hari pertama pelaksanaan pada tanggal 9 november 2020 pukul 13.00 WIB, kegiatan berupa Pengenalan beberapa aplikasi kolaborasi pekerjaan. Kegiatan diawali dengan pemberian google form, tentang pengenalan dan pemahaman peserta tentang google doc. Setelah 15 menit pengisian google form, kegiatan dilanjutkan dengan presentasi dari tim tentang aplikasi kolaborasi, yang berisi tentang pengenalan aplikasi kolaborasi yang berbayar seperti Microsoft word online dan tidak berbayar seperti google docs. Dilanjutkan dengan keunggulan dan kekurangan kedua aplikasi tersebut, fitur-fitur yang dapat digunakan pada kedua aplikasi serta aplikasi pendukung untuk kedua aplikasi tersebut.



\section{Gambar 1. Pembukaan PKM}

Pada sesi ini, ketertarikan peserta untuk melihat langsung perbedaan antara aplikasi berbayar dan tidak berbayar. Peserta berpendapat bahwa aplikasi berbayar $100 \%$ mendekati aplikasi yang biasa digunakan yaitu Micrososft word. Sehingga pemateri menjelaskan secara lebih rinci bagaimana cara untuk menggunakan aplikasi berbayar, mulai dari registrasi, jenis pembelian akun dari untuk pribadi, bisnis hingga pendidikan.

Setelah sesi presentasi masuk sesi tanya jawab selama 30 menit. Selama kegiatan berlangsung para peserta terlihat antusias terhadap materi hari ini karena pertama kalinya peserta baru mendapatkan pelatihan kolaborasi pengerjaan dokumen.

b. Hari kedua pelaksanaan pada tanggal 16 november 2020 jam 13.00, kegiatan ini berupa Pelatihan menyiapkan aplikasi, akun dan kebutuhan lainya, yang berhubungan dengan google docs. Seperti halnya hari pertama, kegiatan dilakukan dengan mendemontrasikan cara masuk kedalam aplikasi google docs, baik dengan menggunakan Personal Computer (PC) atau pun smartphone berbasis android. Kemudian, tim juga mendemontrasikan cara pembuatan dokumen, 


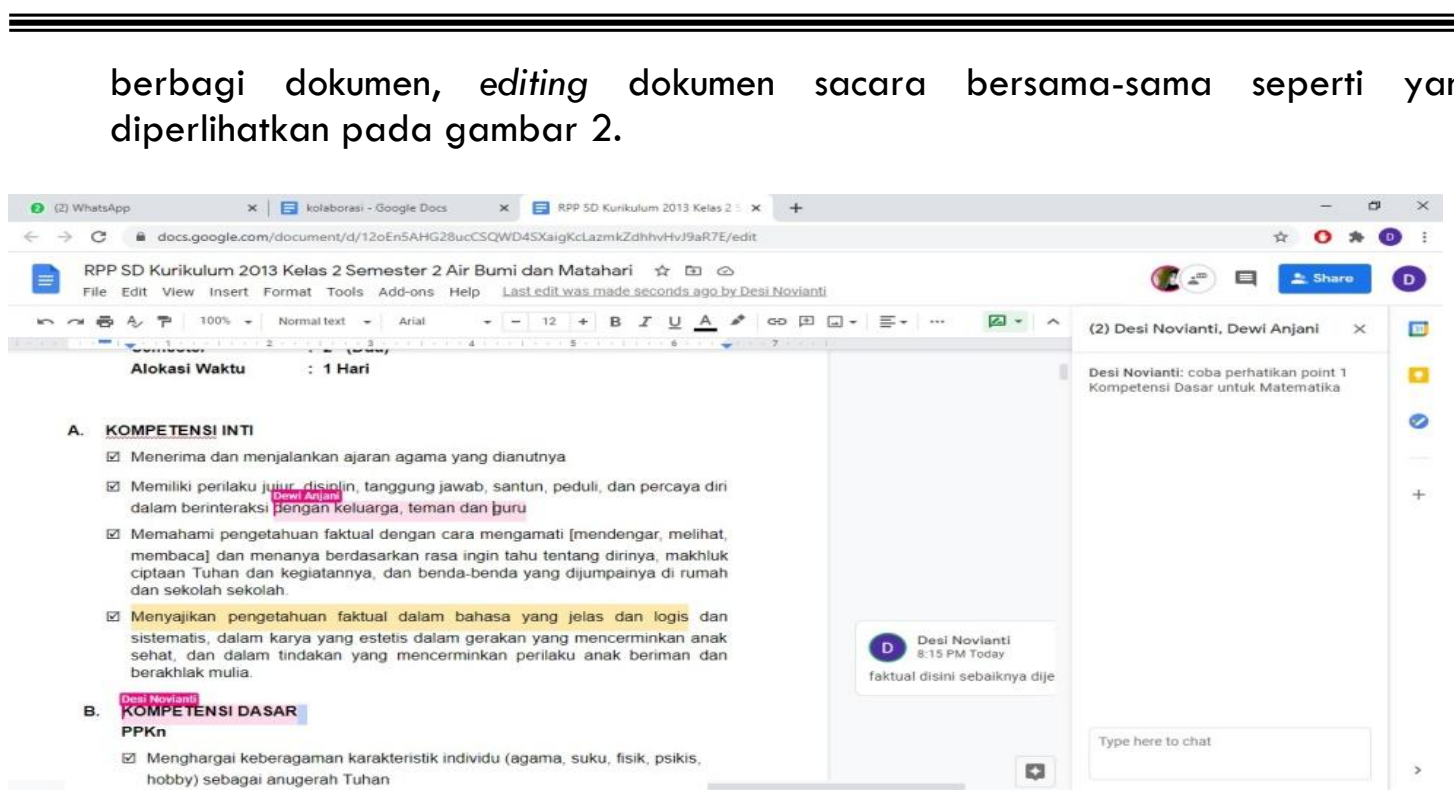

Gambar 2. Tampilan Bekerja secara Kolaborasi

Gambar 2 menampilkan dua orang guru sedang mengubah dokumen yang sama pada waktu yang bersamaan. Proses mengedit dokumen ini tidak akan berbenturan karena setiap guru yang mengetik memiliki tanda seperti warna dan nama akun masing-masing pada kata atau kalimat yang sedang diketik.

Dan tim juga mendemontrasikan cara memberikan komentar dan chat pada saat dokumen dikerjakan. Setelah tim mendemontrasikan, maka masuk sesi tanya jawab sekitar 30 menit, namun terlalu antusiasnya peserta sesi tanya jawab berlangsung menjadi 60 menit dengan beberapa pertanyaan yang belum bisa dijawab pada hari itu.

c. Kegiatan hari ketiga, dimana peserta mendemontrasikan secara langsung pembuatan sebuah dokumen dan mengerjakan secara kolaborasi. Dalam hal ini, peserta dibagi menjadi 10 kelompok yang terdiri dari 3 peserta. Pada hari ketiga, hanya 6 kelompok yang bisa melakukan demontrasi dikarena waktu yang disediakan telah selesai.

Dari 6 kelompok tersebut, terdapat 2 kelompok yang masih kurang optimal, terutama dalam pemberian link dokumen (gambar 3) yang akan dikerjakan.

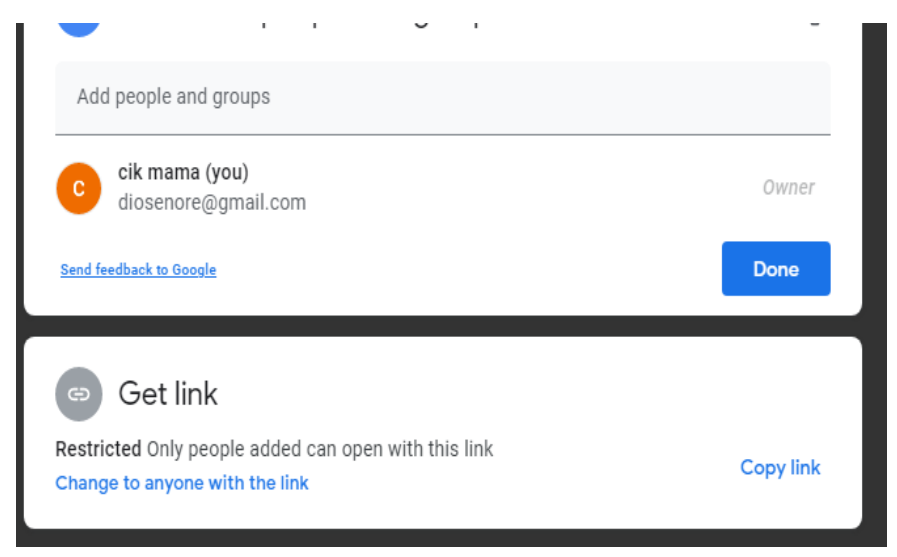

Gambar 3. Tampilan Menu Share dokumen 
Gambar 3 merupakan tampilan bagaimana cara membagi sebuah dokumen keapda rekan kerja. Dalam tahap ini, hala yang paling penting diperhatikan adalah memberikan hak akses (gambar 4) kepada rekan kerja.

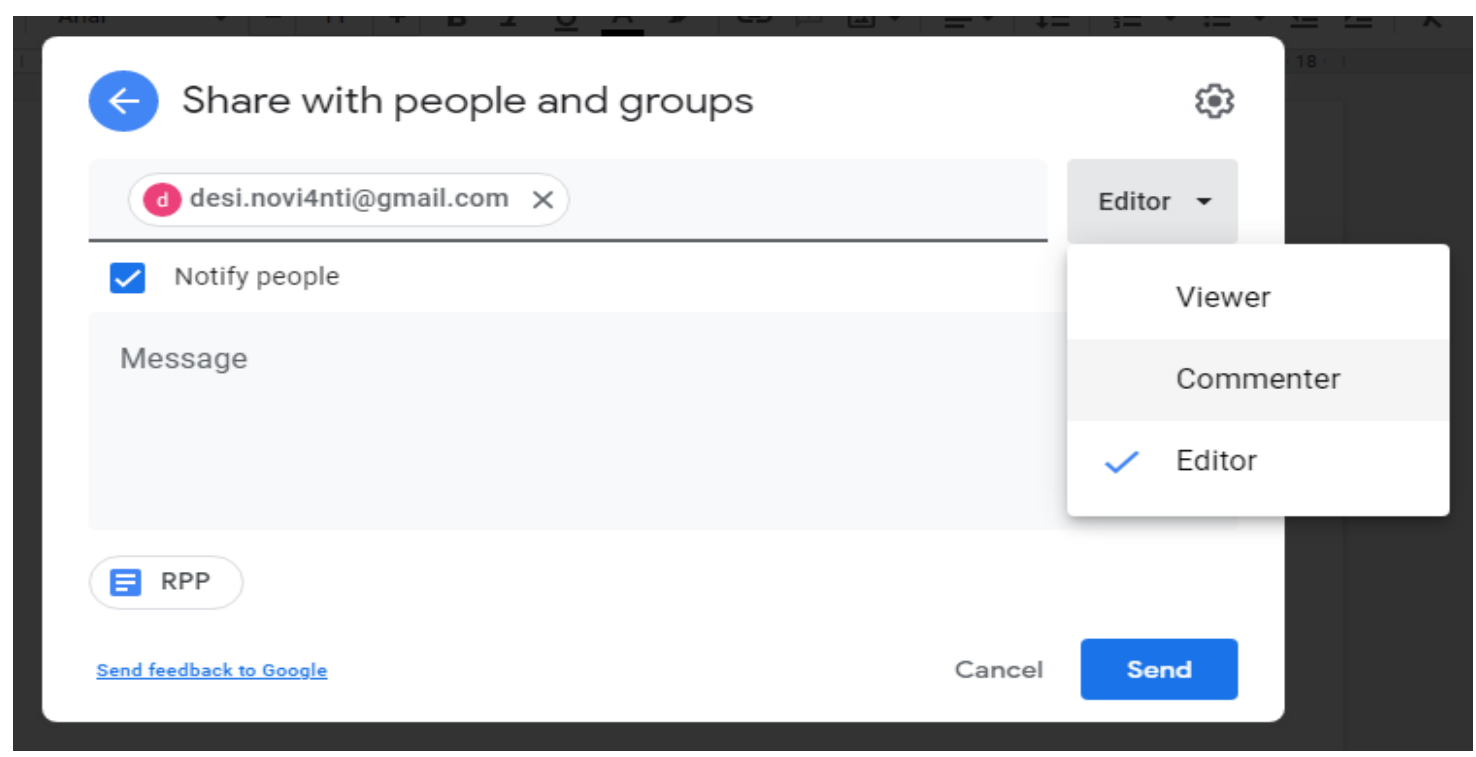

Gambar 4. Tampilan Menu pemberian hak akses dokumen

Pada gambar 4, terlihat bahwa pemberian hak akses ada 3, yaitu :

1. Viewer, dimana apabila peserta memilih menu ini maka rekan kerja hanya dapat melihat dokumen tersebut tanpa bisa mengedit.

2. Commentar, pilihan menu ini hanya memberikan hak akses untuk rekan kerja melihat dan memberikan komentar tanpa bisa bergabung untuk mengerjakan.

3. Editor, menu ini memberikan hak akses kepada rekan kerja untuk melihat, mengubah dan memberikan komentar.

Permasalahan hak akses inilah yang menyebabkan 2 kelompok tersebut kesusahan dalam membagi dokumen. Namun hal ini dapat langsung di tangani oleh pemateri sehingga peserta mampu mendemonstrasikan kembali pekerjaannya.

d. Kegiatan hari keempat, kegiatan pertama melanjutkan demontrasi 4 kelompok yang belum sempat dilaksanakan pada hari ketiga.Kemudian setelah demontrasi, peserta diberikan google form untuk diisi. Materi yang harus diisi sama dengan hari pertama, maksud dari pemberian pertanyaan ini adalah menilai kembali tingkat pemahaman peserta setelah mendapatkan materi.

Pada tahapan pelaksanaan terdapat permasalahan-permasalahan dalam melaksanakan kegiatan PKM ini, diantaranya internet yang tidak stabil yang mengakibatkan gangguan dalam menyampaikan materi sehingga tim harus mengulang materi yang mengakibatkan waktu yang digunakan untuk memaparkan materi lebih banyak. Dan juga peserta yang harus keluar ditengah-tengah kegiatan karena sinyal yang tidak stabeil ini. Permasalahan ini, diselesaikan dengan memberikan rekaman kegiatan, karena tim melakukan perekaman kegiatan menggunakan aplikasi recording yang ada. 


\section{Tahap Evaluasi}

Tahap evaluasi, dimana tim membuat evaluasi kegiatan yang telah berlangsung. Pada hari pertama hasil pengisian google form tentang pengenalan dan pemahaman tentang aplikasi kolaborasi dokumen menggunakan google docs bahwa $86 \%$ peserta sudah mengenal google doc, dari $86 \%$ tersebut diketahui bahwa 56\% sudah pernah menggunakan google doc, namun hanya $1 \%$ saja yang menggunakan google doc sebagai alat untuk pembuatan dokumen secara kolaborasi.

Dari hasil demontrasi 10 kelompok, dapat dianalisis bahwa sekitar $90 \%$ peserta sudah bisa menggunakan google docs sebagai alat untuk membuat sebuah dokumen secara berkolaborasi atau bersama-sama, dimana dibuktinya para peserta sudah dapat membuat dan mendemontrasikan secara baik dan benar. Sementara itu, hasil dari pengisian google form di hari keempat didapat $94 \%$ peserta sudah bisa membuat dokumen dengan cara berkolaborasi

\section{PENUTUP}

Dengan diadakannya kegiatan pengabdian kepada masyarakat yang memperkenalkan dan pemberian Pelatihan Aplikasi Kolaborasi menggunakan google docs. Permasalahnya pembuatan RPP, dimana terlalu banyaknya dokumen dengan nama yang sama sehingga terkadang salah mengedit dokumen. Terlalu banyak waktu tunggu, hingga dokumen yang dikerjakan menjadi lama dalam pengerjaannya semua dapat teratasi.Kegiatan ini juga telah mampu memberikan pengetahuan dan pengalaman baru kepada peserta yaitu guru dalam membuat dokumen secara Bersama tanpa ada batasan ruang dan waktu.

Saran untuk PKM selanjutnya adalah memanfaat Google Workspace lainnya seperti spreadsheet dan slide, serta mengkonversi dokumen tersebut sehingga dapat digunakan secara online atau pun offline.

\section{E. DAFTAR PUSTAKA}

Ananda, R. (2019). Perencanaan Pembelajaran. (Amiruddin, Ed.). Medan: Lembaga Peduli Pengembangan Pendidikan Indonesia (LPPPI).

Baker, K. (2018). The Ultimate Guide to Google Docs. Retrieved from https://blog.hubspot.com/marketing/google-docs

Batara, A. S., Syafar, M., Palutturi, S., \& Stang, S. (2018). Pentingnya Kolaborasi Stakeholder Dalam Mewujudkan Terminal Sehat Di Sulawesi Selatan. MPPKI (Media Publikasi Promosi Kesehatan Indonesia): The Indonesian Journal of Health Promotion, 1(1), 17-20. https://doi.org/10.31934/mppki.v1i1.129

Dolong, H. M. J. (2016). Sudut Pandang Perencanaan dalam Pengembangan Pendidikan. Jurnal Inspirasi Pendidikan, 1(1), 65-76.

Kauffman, R. A. (1972). Educational System Planning. New Jersey: Prentice Hall Inc.

KBBI. (2021). Kolaborasi. Retrieved from https://kbbi.web.id/kolaborasi

Kemdikbud. (2020). Suka duka dalam Proses Pembelajaran Melalui Metode Daring/Luring pada Masa Pandemi Covid19. Retrieved November 3, 2020, from https://guruberbagi.kemdikbud.go.id/artikel/ \%0Akegiatan-ekonomi-masyarakatpada-masapandemi-covid-19

Khumyati. (2017). Peningkatan kemampuan Guru dalam Penyusunan RPP Melalui Kegiatan Supervisi Klinis di MI Nurul Ulum Kesuben Tegal TP.2015/2016. Dialektika Jurnal PGSD, $7(1)$.

Kuswayanto, L. (2006). Mahir berkomputer. Bandung: PT Grafindo Media Pratama.

Lismina. (2017). Pengembangan Kurikulum. (I. Mohtar, Ed.). Ponorogo: Uwais Inspirasi Indonesia.

Majid, A. (2011). Perencanaan Pembelajaran, Mengembangkan Standar Kompetensi Guru 
(edisi 7). Bandung: Remaja Rosdakarya.

Marlina, L. (2017). Perencanaan Pembelajaran Pendidikan Anak Usia Dini. Raudhatul Athfal: Jurnal Pendidikan Islam Anak Usia Dini, 1(2). https://doi.org/10.19109/ra.v1i2.2679

Mawardi. (2019). Optimalisasi Kompetensi Guru Dalam Penyusunan RPP. Jurnal Ilmiah DIDAKTIKA, 20(1), 69-82.

Oviana, W. (2013). Pengembangan Rencana Pelaksanaan Pembelajaran Berbasis Pendekatan Saintifik Oleh Guru SD dan MI di Kota Sabang. Journal of Chemical Information and Modeling, 2(9), 1689-1699.

Sanjaya, W. (2017). Perencanaan Dan Desain Sistem Pembelajaran. Jakarta: Kencana Prenada Media Group.

Siswanto, A. S. K. dan. (2020). Kolaborasi Whatsapp Group, Zoom Cloud Meeting, dan Google Drive Sebagai Formula Dalam Pelaksanaan Kegiatan Perkuliahan Online Di Masa Pandemi Covid-19. Jurnal Media Infotama, 16(2), 61-67. Retrieved from https://jurnal.unived.ac.id/index.php/jmi/article/view/1155/932

Sudjatmiko, T. C., \& Kusrini. (2011). Analisis Perancangan Aplikasi Kolaborasi Dokumen Berbasis Web. Jurnal DASI, 12(4), 22-27.

Sukardjo, M., Khasanah, U., Solehatin, E., \& Sudrajat, Y. (2020). Pelatihan Penyusunan RPP dan Bahan Ajar Bagi Guru Untuk Meningkatkan Kualitas Pembelajaran Di Masa Pandemi. Jurnal Pemberdayaan Masyarakat Universitas Al Azhar Indonesia, 3(1), 15. https://doi.org/10.36722/ipm.v3i1.489

Yatmini. (2017). Meningkatkan Kompetensi Guru Dalam Penyusunan RPP Yang Baik Dan Benar Melalui Pendampingan Berbasis Kkg Semester Satu Tahun 2016/2017 Di SD Negeri Model Mataram. JIME, 2(2), 172-184. 